\title{
Theoretical Analysis of the Framework Lifelong Education on Quality of Life
}

\author{
Winia Waziana ${ }^{*}$, Widi Andewi, Trisnawati, Ponidi \\ Sekolah Tinggi Manajemen Informatika dan Komputer Pringsewu, Indonesia
}

Corresponding Author: Winia Waziana, 2 winiawaziana@gmail.com*

\begin{tabular}{|c|c|}
\hline \multirow[b]{2}{*}{$\begin{array}{c}\text { ARTICLE INFO } \\
\text { Article history: } \\
\text { Received } \\
\text { April 02, } 2020 \\
\text { Revised } \\
\text { May 11, } 2020 \\
\text { Accepted } \\
\text { June 07, } 2020\end{array}$} & ABSTRACT \\
\hline & $\begin{array}{l}\text { The people were created by God with a high desire for intellectual } \\
\text { curiosity. Therefore humans must be able to learn anywhere and anytime, } \\
\text { either in the home, residential environment or educational institutions. } \\
\text { This article was to analyse the strategies in lifelong education. It also } \\
\text { analyses about the importance of education and open their minds that } \\
\text { education is not always obtained from the learning at school. This } \\
\text { research was a qualitative study with content analysis as data collection } \\
\text { techniques. Lifelong education was a system of educational concepts that } \\
\text { includes all activities and learning processes that take place throughout } \\
\text { the whole of human life. The direction of lifelong education was in } \\
\text { children to adults in order to increase their knowledge and skills that are } \\
\text { needed to survive and have a better quality of life. }\end{array}$ \\
\hline How to cite & $\begin{array}{l}\text { Keywords: Framework Lifelong Education, Quality of life } \\
\text { Waziana, W., Andewi, W., Trisnawati, T., \& Ponidi, P. (2020). Theoretical } \\
\text { Analysis of the Framework Lifelong Education on Quality of Life. Jurnal Iqra' } \\
\text { Kajian Ilmu Pendidikan, 5(1).71-84. https:// doi.org/10.25217/ji.v5i1.648 }\end{array}$ \\
\hline $\begin{array}{l}\text { Journal Homepage } \\
\text { This is an open acces }\end{array}$ & $\begin{array}{l}\text { http://journal.iaimnumetrolampung.ac.id/index.php/ji/ } \\
\text { article under the CC BY SA license }\end{array}$ \\
\hline Published by & $\begin{array}{l}\text { https:// creativecommons.org/licenses/by-sa/ } 4.0 \text { / } \\
\text { Institut Agama Islam Ma'arif NU (IAIMNU) Metro Lampung }\end{array}$ \\
\hline
\end{tabular}

\section{INTRODUCTION}

The school has become a formal institutional system that is facilitated by building facilities and supporting devices for other learning activities. Automatically it takes a fee to enter the place that was originally a filler of this free time. So those who do not have money to pay for school are considered as uneducated people (Aini \& Muzakkar, 2014). Education has been started since humans were created. But many people forget it because of the superficial meaning of school and learning. Yet what we think, say, and do every day to anyone and anywhere is a learning process in the school of life or can be called a university of life.

Education is a phenomenon inherent in human life, in which there is always an effort to humanize humans themselves (Pedersen \& Pini, 2017; Levine \& White, 2017). Philosophically, it can be said that the essence of education is the process of developing all the potential of humanity, both the physical and spiritual aspects, towards a better, more perfect and wiser. The basis of education will determine the style and content of education. The purpose of education determines the direction in which students will be brought (Nata, D. H. A. 2016). Education is not a simple matter, so it requires a 
relatively long time, so the concept of lifelong education becomes something important and needs to be studied in more depth.

According to (Mawardi, 2011), inherently, humans have desires or dignity, even in a different order. Desire is the requirement of fulfilling the needs of clothing, food, shelter and spiritual health, as well as the need for selfactualization, namely the need for recognition of one's existence in front of others. In the context of education in Indonesia, as one of the considerations of the President of the Republic of Indonesia in stipulating Law No. 14 of 2005, it is said that national development in the field of education is an effort to educate the life of the nation and improve the quality of Indonesian people who have faith, piety and noble character and master science, technology, and art in realizing an advanced, just, prosperous, and civilized society based on Pancasila and the 1945 Constitution of the Republic of Indonesia (Aripin \& Alton, 2010).

In this case education can be said to carry a very noble mission, very heavy and very wide field of work, so it is impossible to succeed if the affairs of education are only left to certain parties or institutions, with low energy and in a relatively short time. Therefore, the concept of lifelong education should be the principle of implementing development in the field of education. According to the report of the Program for International Student Assessment (PISA) in 2015 - a program that ranks the quality of the education system in 72 countries, - Indonesia ranked 62nd. Two years earlier (PISA 2013), Indonesia ranked second from the bottom or ranked 71 (Sidharta, 2017). Then in 2017 Indonesia entered the world education ranking or the World Education Ranking published by the Organization for Economic Co-operation and Development (OECD). As reported by The Guardian, Indonesia ranks 57th out of a total of 65 countries in terms of reading, mathematics, and science. The problem of limited education generally stems from poverty and is a very complicated problem because it is related to other major problems, such as lack of nutritious food intake, lack of access to information, and other problems. Indonesia has launched an education reform program to improve the quality of this sector for 15 years since 2002. World Bank head representative for Indonesia Rodrigo Chaves said the low quality of education is reflected in Indonesia's ranking which is still in the highest position from neighboring countries (Fauzie, 2018). This education quality ranking indicator is reflected in the number of illiterate cases.

Some factors of the community experiencing illiteracy are among others caused by people in the area who can only speak the local language and do not understand Indonesian, as well as the development era and technology. Most illiterates are the older generation who are not familiar with technology (Kennedy, 2017; Fall, 2020). Furthermore, social differences in society between the rich and the poor and the emergence of various groups or social statcgbus in society. Status is a social ranking based on prestige such as prestige, dignity, and authority. Status is generally based on differences in occupation, sociology, 
and descent. However, the government has done many ways to reduce and prevent the level of illiteracy is decreasing.

Recent study that discussed about long life education was reported by with the title Long Life Education-Belajar Tanpa Batas. The result showed that education in the conception of Islam has two important ranges, namely the optimal development of self-potential and perfection. The second study was Jannah (2013) with the title of Lifelong Education and Its Implications. The implications of lifelong education in educational programs can be grouped into functional literacy, vocational education, professional education, education towards change and development and citizenship education and political maturity (Hodge et al., 2017; Ibatova et al., 2016) . The third study was research by Huda (2019) with the title of Lifelong Education in Islam Perspective. In this article, Life long Education in Islamic Education is a process of activity. The activity includes attention, guidance, and assistance to the formation of individual behavior and it is a concept adhering to the stages of human development. Fourth is research by (Sada, H. J. 2015). The results of the study stated that the Lifelong Education Concept included an idea that contained the principles of school organizing to help the lifelong learning process, namely formal and informal education. Then the concept of education in Islam covers human nature in seeking knowledge. The concept of lifelong education is in harmony with Islamic education.

The previous studies above have explained the importance of lifelong education, but the researchers was to develop the results of thought from these studies. This research developed theories and strategies in lifelong education. It was important because, the need for education is also growing. To be able to better understand and open up thinking about the importance of life well education as well as the urgency about lifelong education as a basis for implementing education. It is necessary to study and analyze the theoretical framework of lifelong education on quality of life. Hence, it is illustrated about the importance of the concept of lifelong education in the education process. This study hypothesizes are that lifelong education is character education, which includes hard skills and soft skills. Every individual must improve their quality of life with education.

\section{METHODS}

The research is qualitative study. It includes the process of exploring and understanding the meaning of individual and group behavior, describing social problems or humanitarian problems (Killam \& Heerschap, 2013; Conway, 2014; Moser \& Korstjens, 2018). This type of research is a literature study or literature study that contains theories that are relevant to research problems. This section reviews the concepts and theories used based on the available literature, especially from articles published in various scientific journals. A literature study serves to build concepts or theories that form the basis of study in research. After all the data has been collected, the next step is to analyze the data so that a conclusion is drawn (Arikunto, 2010). Literature study or 
literature can be interpreted as a series of activities relating to the method of collecting library data, reading and recording and processing research material (Mulyatingingsih \& Nuryanto, 2014). The method of collecting data in this study is documentation, which is collecting data and information from some relevant literature. This means that the researcher examines and/or explores several journals, books, and documents (both printed and electronic) as well as other sources of data and/or information deemed relevant to research or studies. The data analysis technique used is content analysis, which is a technique used to analyze and understand the text.

Content analysis is a research technique for making replicable and valid inferences from texts (or other meaningful matter) to the contexts of their use. As a technique, content analysis involves specialized procedures. It is learnable and divorceable from the personal authority of the researcher. As a research technique, the content analysis provides new insights, increases a researcher's understanding of particular phenomena, or informs practical actions (Krippendorff, 2018). The stages to be carried out in this study are the first is determining the theme. At this stage, researchers conducted more observations of data in the form of documents. Look for topics of interest and in this study topic of interest to researchers are finding a framework for a lifetime education the second is formulating the Problem. This stage is the reason why a topic is decided to be tested. This is done by researchers to formulate the problem with the chosen theme. The third is Collect data and determine research methods. Namely conducting theoretical studies related to the research topic. Literature sources can be obtained from books, journals, magazines, news, research results (thesis, thesis, and dissertation) and other relevant sources. The fourth is Analyze and compile the data findings. The last is draw conclusions. This stage is the answer to the research objectives which are at the conceptual/theoretical level. Researchers regularly arrange the data obtained so that they can conclude from the data that has been collected

\section{RESULT AND DISCUSSION}

Based on the background of the problems and objectives of this study, namely the importance of lifelong education as well as the theoretical and strategic framework on lifelong education as the basis for implementing education; from some data references, the following results are obtained: Education is a conscious and planned effort to create an atmosphere of learning and learning process so that students actively build their potential to have spiritual, religious, self-control, personality, intelligence, noble character, and skills needed by themselves, the community, the nation, and the State (Syafril, 2019). Science and education cannot be separated from the movement and development of humans on this earth. This is because science itself plays an important role in human civilization. Likewise, the Al-Qur'an is a source of knowledge and guidance for life for all mankind. The fall of the Al-Qur'an is a form of love from Allah SWT. "Then the Highest Allah, the true King, and do not be 
hasty in reading the Qur'an before completing it, reveal it to you, and say: "O my Lord, add to my knowledge"

Allah requires his servants to seek knowledge, which means that Allah does not want Muslims to be ignorant, lacking association, lacking updates and so on which makes one lag behind others (Rachmawati, 2015). Demanding knowledge is very important because, without knowledge, there is very little that humans can do in their lives. Lifelong education or lifelong learning does not mean you have to go to school all your life. Huda (2019) asserted lifelong education refers to a set of extrinsic factors, oriented towards identifying needs and providing facilities. Lifelong learning is intrinsic, demand-oriented and highly dependent on the motivation and ability of individual learners. Both are closely related and there must be a balance to increase synergies and productive results. Close relationship Lifelong education and Lifelong learning can be described through the Damn cycle.

Figure 1 : The Damn cycle

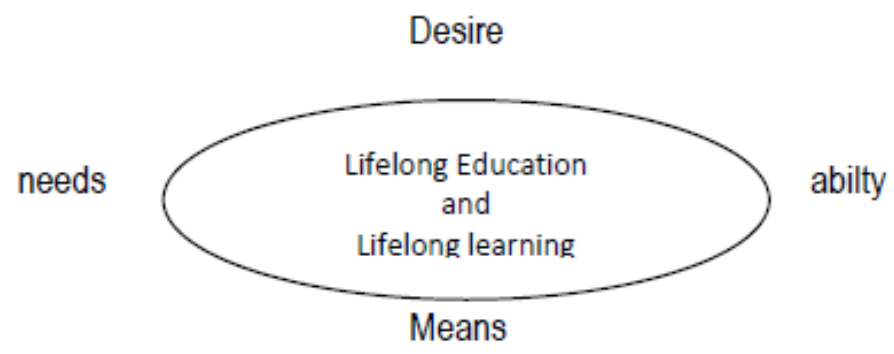

Adapted from Pan at (Huda, 2019)

The Damn cycle is an overlapping circle that is related to wants, abilities, facilities, and needs. The Damn circle is where the lifelong education and lifelong learning which both complement each other. Lifelong education is that all individuals must have systematic, organized opportunities for introduction, learning at every opportunity throughout their lives (Leung, 2011). Lifelong learning is a personal process. That is something people do. Conversely, lifelong education is an institutional fact (Searle, at Billet), which arises from and is enforced by the social world, usually in the form of providing certain types of experiences. Lifelong learning is something that happens all the time as individuals think and act, some of which happens through their involvement in educational programs and institutions namely, lifelong education (Billett, 2018).

Education is interpreted by many people as a learning task that is trapped in a "space" called "School". This learning paradigm must be changed immediately. Understanding learning not only in the room but learning in all places, all situations, and all things. Learning means the functioning of life, people who do not learn have lost their lives, and at least they have lost their lives as humans. Because human life is not only an individual in himself but also interact with each other, with between generations and life universally. 
Furthermore, the findings some theories in lifelong education study are as follow:

\section{Lifelong Education}

Education basically involves all life experiences. Thus education is life and life is education (Zuhri \& Mudhofar, 2014). Education in Islam does not always rely on morals that are limited to the relationship between the servant and his Lord but also includes relationships with fellow humans and with the safety of the surrounding natural environment. This scope is in line with the mission of the Caliphate that must be played by humans. This means that education lasts a lifetime. Lifelong education is mental growth, personality development, social growth, economy, and culture. All of them continue for a lifetime (Retno, 2017). In lifelong education to be able to maintain existence in life, it is several things that need to be done to hone the potential for hard skills and soft skills (Prilianti, 2012) namely: Learning to know, Learning to do, Learning to live together, that is learning to live with others. Is how can we live together with other people who have different backgrounds, cultures, social, economic and religious and diversity. The term lifelong education (Life Long Integrated Education) cannot be replaced by other terms, because the contents and breadth (scope) are not the same, such as the terms out of school education, continuing education, adult education, further education, recurrent education (Griffin, 2018; Kadir, 2015). Lifelong education can also be understood as a principle that the education process is a continuous process, which began when someone was born and even said before humans were born to die. This implies that education is a series of activities that occur continuously, covering all aspects of life and requires a relatively long time.

\section{Rationale and Urgency of Lifelong Education}

According to Syamsi (2010) that the education process can take place at any time wherever and whenever with no age limit. The statement is following the phrase "Education is Life Long". An idea like this was also put forward by John Dewey that: the Educational process has no end beyond itself in its own and end. In this context lifelong education refers to reality, a new awareness, a new principle, and also a new hope that the educational process and educational needs take place throughout human life (Wain, 2016). Thus there is no term "too late", "too old", or "too early" to learn. According to (Ihsan, 2010) that the urgency of lifelong education can be reviewed in several aspects, including:

The ideological aspect, namely that every human being born into this world has the same right to obtain an education, increase knowledge and increase his skills. Lifelong education will provide a great opportunity for every individual to develop their potential in life.

Economic aspects, education is the most effective way to get out of the "poverty-environment" due to ignorance. Lifelong education will provide an opportunity for someone to increase productivity, maintain and develop 
their resources, live in a pleasant and healthy environment, and have motivation in educating children properly so that family education becomes important.

Sociological aspects, in developing countries many parents are less aware of the importance of school education for their children, some dropout and some do not go to school at all, lifelong education for parents is a problem solving of the phenomenon.

Political aspects, citizenship education needs to be given to all people to understand their duties, rights, and obligations as well as the functions of the government, the Parliament, the People's Consultative Assembly, and other state institutions. The task of lifelong education as a civic education needs to be given to every citizen without exception.

Technological aspects, lifelong education as an alternative for scholars, technicians, and leaders in developing countries to update their knowledge and skills as developed countries do.

Psychological and pedagogical aspects, along with the broader, deeper and complex science, it is no longer possible to be taught entirely in schools. The task of school education is only to teach students about learning methods, instill strong motivation to continuously learn throughout life, provide skills quickly and develop adaptability. To implement lifelong education, an atmosphere conducive to the implementation of education needs to be created.

The application of ways of thinking according to the principle of lifelong education will change our view of the status and function of the school, where the main task of school education is to teach students how to learn, the role of the teacher is primarily as a motivator, stimulator and student's guide in terms of learning, school is the center of the learning activities of surrounding communities. So in the context of the view of lifelong education, all people are potentially students.

\section{Lifelong Education Theoretical Framework}

Education is a very complex and long-term process, in which various aspects involved in the process are closely related to each other and lead to the realization of human beings who have life values, life knowledge, and life skills. This means that in general education has very complex goals as well. Likewise for life education, an educational concept certainly has a clear goal as an ideal picture to be achieved by the existence of the concept. Theoretically, the framework for a lifetime education consists of a description of the meaning of life, a lifetime, and education. Hoque (2019) described life, life, and education.

a) Life

There are three interrelated components, namely: Individuals as members of society who have certain characteristics. Second the Community, which is a social environment, which can take the form of psychological groups and social organizations. Third is the physical environment or natural environment, where humans live (habitat) as individuals and members of the community. 
b) A lifetime

A lifetime, it means that every human individual experience a period of personality development, which includes physical, mental, social, and emotional development. Then there are stages of development, which include infancy, childhood, childhood, adolescence, adulthood, and old age. Then it covers general professions, for example as teachers, doctors, lawyers, traders, and so on.

c) Education

Education as an effort to achieve the development and change of behavior of each individual through life, which includes three components, namely:

a. Educational foundation, namely the concepts of sociological, economic, political, demographic, ecological, philosophical, biological, psychological, and other branches of science, which are the basis for the implementation or practice of education.

b. Methods of communication, verbal-nonverbal, with or without teaching and learning aids, which are used in educational practice at school or outside school.

c. The content of education, in the form of knowledge, skills, and values that become teaching material in education. Teaching materials in education can be in the form of cultural stock in the form of science, art, and human ideals and the development of new and obsolete knowledge.

The conception of lifelong education in Indonesia has been stated several times in the GBHN, but its implementation often changes. The concept within the GBHN is still very broad in its meaning, so there is often "flexibility" in interpreting it so that at the implementation level it becomes very diverse. For example, in taking a stand between the various interpretations of education those are academic in nature and operational techniques, as well as between formal education and school education with non-formal education. The formal education pathway has supported lifelong education by including character education in the school education curriculum.

\section{Lifelong Education Direction and Strategy}

Ihsan (2010) explained that in general lifelong education is directed at adults and children in order to increase their knowledge and skills that are needed in life.

a) Lifelong Education for Adults

As the next generation, young people or adults need a lifetime of education in order to fulfill the nature of "Self Interest" which is the guidance of life for all time. Among them are the need to read and write for them in general and skills training for workers, greatly helping them to deal with situations and important issues that are the key to success.

b) Lifelong Education for Children

Lifelong education for children is another side that needs attention and fulfillment because children will be a "starting place" for adults meaning with all the advantages and disadvantages. Knowledge and abilities of children 
provide great opportunities for development in adulthood. And in turn, his adult life bears the burden of a lighter life. The educational process emphasizes the methodology that teaches because the child must be embedded in learning keys, learning motivation and a strong learning personality. Yusuf in (Ihsan, 2010) explained that the program of activities was arranged starting to increase literacy skills, basic skills and enhance children's thinking power, thus allowing children to get accustomed to learning, thinking critically and having a vision of life in the future.

No general theory of adult or lifelong education is possible which does not have the context and processes of adult learning as a primary object. for the importance of the curriculum is that of education itself, and those who have been seriously concerned with education have necessarily found it of interest (Griffin, 2018). But in an educational context, he has a strategy in learning. The strategy in the framework of a lifetime education as outlined in (Ihsan, 2010), that the key concepts of a lifetime education include the following:

a) The Concept of Lifelong Education itself

The concept of lifelong education is defined as a formal goal or structuring of educational experiences, both in the form of formal and non-formal education that is useful for developing one's abilities.

b) The Concept of Lifelong Learning

This concept leads to learning activities that can be done anywhere and anytime and about anything that can develop self-potential.

c) The Concept of a Lifelong Learning Method

Learning does not have from someone who called as a teacher but to learn from people who are experts in a field, regardless of age, status and so on.

d) The curriculum that Helps Lifelong Education

In this context, the curriculum designed on the principle of lifelong education, the material is a social phenomenon that occurs every day. So they know their strengths and weaknesses.

To produce a superior educational process, each curriculum must be arranged and developed and adapted to the needs of the community. The curriculum is demanded to always be dynamic in following the development of society and science, experiencing change, improvement and even continuous renewal (Nurhalim, 2011). The formal education curriculum (school) in Indonesia currently uses the 2013 curriculum and is still being developed. The 2013 curriculum emphasizes the modern pedagogical dimension in learning, which uses a scientific approach in learning as referred to including Observing, Questioning, Associating, Experimenting and Networking (Muhammedi, 2016). The curriculum 2013 is more emphasized on the competency-based on attitudes, skills, and knowledge of the curriculum that can produce Indonesian people who are Productive, Creative, Innovative, Affective through strengthening integrated Attitudes, Skills, and Knowledge. The core concept of the 2013 curriculum has several similarities with the basic concept of lifelong education where the result is an increase and balance between the ability to be 
good human beings (soft skills) and people who have the skills and knowledge to live properly (hard skills)

\section{Education and Quality of Life}

Education is one of the most important aspects of human life. Education is also a social tool to achieve social goals, which can be useful to ensure one's survival. Education is also one indicator in measuring the welfare of the community. A society with a high level of education is also expected to have a high quality of life so that welfare can be achieved (E. N. Aini et al., 2018). Welfare is a condition of society that can live properly and can meet the needs of life. The welfare measure can be seen from the income obtained. Education is an important factor that can affect household income and welfare (Mahendri, 2019).

The findings from the research show that the theoretical analysis of the framework of a lifetime education on the quality of life is a lifetime education involve character education, which is focused on hard skills and soft skills that have learning methods and curriculum. Every individual must improve their quality of life with education. Education is a factor that can affect the level of quality of life. Theories that support the importance of lifelong education are theories about education, the urgency of education, the educational framework, the direction and strategy of education, and the relationship of education with quality of life. Educated individuals will find it easier to find solutions to the problems they face. Education has a relation to socioeconomic status is related to self-acceptance, life goals, positive relationships, and self-growth. Differences in psychological - socioeconomic status are closely related to a person's physical and mental well-being. Then every individual must be educated to have a better quality of life. Education can be obtained from anywhere, anytime regardless of age, status, and so on. This research produces theories that describe a lifelong educational framework that is more universal.

The findings of previous studies were different from this current research. The results of the previous research above are taken from the perspective of Islam with the results of the study: Lifelong education in the view of Islamic education is a process of activities that includes attention, guidance, and assistance for the formation of individual behavior and help also develop aspects of individual growth, common sense, body, social, psychological, moral, and many more from in the womb until his death to get blessings from Allah SWT (Huda, 2019). The education process starts from choosing a mate, have children, to adulthood, or baligh. Informal education is centered on parents and family (Bakri, 2014). Furthermore, the results of this study are supported by the results of research by (Arba'iyah, 2012). Islam explains that education takes place since the spirit is blown into the body and ends until the period of business in the world is over. This means that the educational process in the next generation begins when prospective parents choose a life partner. The same concept becomes one of the important foundations why education must last a lifetime besides that the pace of change 
requires humans to continue the educational process with the hope of becoming an ideal human being in the world dimension and happy in the hereafter (Zuhri \& Mudhofar, 2014). There is no age limit for a Muslim to study; the only limitation for the compulsory study is death (Bimosekti, 2016). The concept of a Lifelong Education is based solely on the fulfillment of human needs according to their age range and is more humanistic oriented. This concept is difficult to apply in a formal environment. Instead, the concept is in harmony if applied in an informal setting, for example in pesantren education where the educational process can be very intense, this concept can also be applied in the family and community environment.

\section{CONCLUSIONS}

Lifelong education is a system of educational concepts that includes all activities and learning processes that take place throughout the whole of human life. The process of lifelong education takes place continuously, not limited by time and place as well as formal education, the process of lifelong learning is not only carried out by a particular person or group, but all levels of society can carry it out. Theoretically, the framework of a lifetime education consists of a description of the meaning of life, a lifetime, and education that is education as an effort to achieve the development and change of behavior of each individual through life, which involves each individual, society and environment, which includes stages Development from infancy to old age occurs in all dimensions of personality development and involves various roles in society. Lifelong education strategy is an educational concept, a learning concept, a learning method, and a curriculum. The direction of lifelong education is in children to adults, both men, and women, in order to increase their knowledge and skills in order to have hard skill and soft skills, shape their character and quality, benefit others, in order to survive and have a better quality of life.

\section{ACKNOWLEDGMENTS}

Alhamdulillahi Rabbil 'Alamin, the researchers expresses her highest gratitude to Allah Subhanahu Wa Ta'ala for blessing love, opportunity, health, and mercy to complete the journal with the title: Theoretical Analysis of the Framework of a Lifelong Education on Quality of Life. Finally, we would like to thank everybody who was important to the successful realization of this journal. Thanks for Trinsawati for the guidance who has given motivation to authors to immediately complete this research. Thank you also expressed to all students for their contribution in helping collect data and in testing research book products

\section{AUTHOR CONTRIBUTION STATEMENTS}

The author had participated in the research and approved the final version of the manuscript. 


\section{REFERENCES}

Aini, E. N., Isnaini, I., Sukamti, S., \& Amalia, L. N. (2018). Pengaruh Tingkat Pendidikan Terhadap Tingkat Kesejahteraan Masyarakat di Kelurahan Kesatrian Kota Malang. Technomedia Journal, 3(1), 58-72. https://doi.org/10.33050/tmj.v3i1.333

Arikunto, S. (2010). Prosedur penelitian. Google Scholar

Aripin, S., \& Alton, L. (2010). Implementasi Undang-Undang Nomor 14 Tahun 2005 Dalam Peningkatan Kualifikasi Akademik Guru SD Melalui Pendidikan Tinggi Jarak Jauh Di Wilayah Kabupaten Belitung. Jurnal Pendidikan Terbuka Dan Jarak Jauh, 11(1), 35-43.. Google Scholar

Aini, I. D., \& Muzakkar, M. (2014). Perempuan Pembelajar. Elex Media Komputindo. Google Scholar

Arba'iyah, Y. (2012). Long Life Education_Belajar Tanpa Batas. PEDAGOGIA: Jurnal Pendidikan, 1, 111-130. https://doi.org/10.21070/pedagogia.v1i2.35

Bakri, M. A. (2014). Long Life Education Dalam Perspektif Islam. PILAR: Jurnal Ilmu-ilmu Agama Kontemporer, 3(2). Google Scholar

Billett, S. (2018). Distinguishing lifelong learning from lifelong education. Journal of Adult Learning, Knowledge and Innovation, 2(1), 1-7. https:/ / doi.org/10.1556/2059.01.2017.3

Conway, C. M. (2014). The Oxford Handbook of Qualitative Research in American Music Education. Oxford University Press. Google Scholar.

Fall, M. (2020). The Impact of Mother Tongue Illiteracy on Second Language Acquisition: The Case of French and Wolof in Senegal. Routledge. Google Scholar

Fauzie, Y. (2018). Bank Dunia: Kualitas Pendidikan Indonesia Masih Rendah. Online),(https://www. cnnindonesia. com/gaya-hidup/20180607113429-284304214/bank-dunia-kualitas-pendidikan-indonesia-masih-rendah., diaksespada 28 januari 2019). Google Scholar

Griffin, C. (2018). Curriculum theory in adult and lifelong education. Routledge. Google Scholar

Hoque, M. M., King, E. M., Montenegro, C. E., \& Orazem, P. F. (2019). Revisiting the relationship between longevity and lifetime education: global evidence from 919 surveys. Journal of Population Economics, 32(2), 551-589. https:// doi.org/10.1007/ s00148-018-0717-9

Hodge, S., Holford, J., Milana, M., Waller, R., \& Webb, S. (2017). Vocational education and the field of lifelong education. International Journal of Lifelong Education, 36(3), 251-253. https:/ / doi.org/10.1080/02601370.2017.1306357

Huda, M. (2019). Life Long Education in Islamic Perspective. International Journal of Nusantara Islam, 7(1), 40-48. https:// doi.org/10.15575/ijni.v7i1.4006

Ibatova, A. Z., Ippolitova, N. V., Mukhametgaliyeva, S. K., Rodionova, A. E., Yagafarova, K. N., \& Ikonnikova, L. N. (2016). Lifelong Professional Education in the Russian Federation: Personal Aspect. International 
Journal of Environmental and Science Education, 11(16), 9426-9436. Google Scholar

Jannah, F. (2013). Pendidikan Seumur Hidup dan Implikasinya. Dinamika Ilmu, 13(1). https:/ / doi.org/10.21093/di.v13i1.19

Kadir, A. (2015). Dasar-dasar pendidikan. Kencana. Google Scholar

Kennedy, M. (2017). Illiteracy as Immanent: The (Re)Writing of Rhetoric's Nature. Google Scholar

Krippendorff, K. (2018). Content analysis: An introduction to its methodology. Sage publications. Google Scholar

Killam, L. A., \& Heerschap, C. (2013). Challenges to student learning in the clinical setting: A qualitative descriptive study. Nurse Education Today, 33(6), 684-691. https:/ / doi.org/10.1016/j.nedt.2012.10.008.

LeVine, R. A., \& White, M. I. (2017). Human conditions: The cultural basis of educational developments (Vol. 32). Routledge. Google Scholar

Leung, D. S., \& Liu, B. C. (2011). Lifelong education, quality of life and selfefficacy of Chinese older adults. Educational Gerontology, 37(11), 967-981. https:/ / doi.org/10.1080/03601277.2010.492732

MAHENDRANI, S. P. (2019). Pengaruh Pendidikan Terhadap Kesejahteraan Tiga Kelompok Pendapatan Masyarakat Di Indonesia (Doctoral dissertation, Universitas Airlangga). Google Scholar

Mawardi, I. (2011). Transinternalisasi budaya pendidikan islam: membangun nilai etika sosial dalam pengembangan masyarakat. HUNAFA: Jurnal Studia Islamika, 8(1), 27-52, https:/ / doi.org/10.24239/jsi.v8i1.83.27-52

Moser, A., \& Korstjens, I. (2018). Series: Practical guidance to qualitative research. Part 3: Sampling, data collection and analysis. European Journal of General Practice, 24(1), 9-18.

https:/ / doi.org/10.1080/13814788.2017.1375091

Muhammedi, M. (2016). Perubahan Kurikulum Di Indonesia: Studi Kritis Tentang Upaya Menemukan Kurikulum Pendidikan Islam Yang Ideal. RAUDHAH, 4(1). http:/ / dx.doi.org/10.30829/raudhah.v4i1.61

Mulyatiningsih, E., \& Nuryanto, A. (2014). Metode penelitian terapan bidang pendidikan. Google Scholar

Nata, D. H. A. (2016). Ilmu pendidikan islam. Prenada Media. Google Scholar

Nurhalim, M. (2011). Analisis Perkembangan Kurikulum di Indonesia (Sebuah Tinjauan Desain Dan Pendekatan). INSANIA: Jurnal Pemikiran Alternatif Kependidikan, 16(3), 339-356. https://doi.org/DOI: https:/ / doi.org/10.24090/insania.v16i3.1597

Prilianti, R. (2012). Pengembangan Perangkat Pembelajaran Pendalaman Materi Kimia Redoks Berbasis Empat Pilar Pendidikan Melalui Lesson Study. Google Scholar

Pedersen, H., \& Pini, B. (2017). Educational epistemologies and methods in a more-than-human world. Educational Philosophy and Theory, 49(11), 10511054. https://doi.org/10.1080/00131857.2016.1199925 
Rachmawati, E. (2015). Manusia Yang Berilmu Berusaha Memenuhi Kebutuhan Hidupnya Untuk Mencapai Aktualisasi Diri. Sustainable Competitive Advantage (SCA), 5(1). Google Scholar

Retno, S. M. (2017). Konsep pendidikan seumur hidup menurut Ronggowarsito dalam kitab Wirid Hidayat Jati (Tinjauan teori Pendidikan Islam) (Doctoral dissertation, IAIN Ponorogo). Google Scholar

Sada, H. J. (2015). Konsep Pembentukan Kepribadian Anak Dalam Perspektif Al-Qur'an (Surat Luqman Ayat 12-19). Al-Tadzkiyyah: Jurnal Pendidikan Islam, 6(2), 253-272. https:/ / doi.org/10.24042/ atjpi.v6i2.1517

Syafril, M. P., \& Zen, Z. (2019). Dasar-Dasar Ilmu Pendidikan. Prenada Media. Google Scholar

Syamsi, I. (2010). Pendidikan Luar Sekolah Sebagai Pemberdaya Dalam Masyarakat. Diklus, 14(1). Google Scholar

Sidharta, J. (2017). Peringkat Pendidikan Indonesia di Dunia. Tersedia di https://www. youthcorpsindonesia. org/l/peringkat-pendidikan-indonesia-didunia/(diakses 12 Februari 2019). Google Scholar

Wain, K. (2016). Philosophy of Lifelong Education. Routledge. Google Scholar

Zuhri, S., \& Mudhofar, M. (2014). Konsep pendidikan seumur hidup dalam perspektif filsafat pendidikan islam. Jurnal pusaka, 2(1). Google Scholar

Copyright Holder :

(c) Waziana, W., Andewi, W., Trisnawati, T., \& Ponidi, P. (2020)

First Publication Right :

(C) Jurnal Iqra' : Kajian Ilmu Pendidikan

This article is under:

(우(1) 